\title{
Chemical Species of
} Migrating Radionuclides at Commercial Shallow Land Burial Sites

Quarterly Progress Report

May-July, 1984

L. J. Kirby

W. H. Rickard

August 1984

Prepared for

the U.S. Nuclear Regulatory Commission

under Contract DE-AC06-76RLO 1830

NRC FIN B2291

Pacific Northwest Laboratory

Operated for the U.S. Department of Energy

by Battelle Memorial Institute 


\section{DISCLAIMER}

This report was prepared as an account of work sponsored by an agency of the United States Government. Neither the United States Government nor any agency thereof, nor any of their employees, makes any warranty, express or implied, or assumes any legal liability or responsibility for the accuracy, completeness, or usefulness of any information, apparatus, product, or process disclosed, or represents that its use would not infringe privately owned rights. Reference herein to any specific commercial product, process, or service by trade name, trademark, manufacturer, or otherwise, does not necessarily constitute or imply its endorsement, recommendation, or favoring by the United States Government or any agency thereof. The views and opinions of authors expressed herein do not necessarily state or reflect those of the United States Government or any agency thereof.

PACIFIC NORTHWEST LABORATORY operated by

BATTELLE

for the

UNITED STATES DEPARTMENT OF ENERGY

under Contract DE-AC06-76RLO 1830 
PNL-4432-9

(FY 84 THIRD

QUARTER)

CHEMICAL SPECIES OF MIGRATING

RADIONUCLIDES AT COMMERCIAL

SHALLOW LAND BURIAL SITES

QUARTERLY PROGRESS REPORT

April-June, 1984

L. J. Kirby

W. H. Rickard

August 1984

Prepared for the

U.S. Nuclear Regulatory Commission under Contract DE-AC06-76RL0-1830

NRC FIN B229l

Pac if ic Northwest Laboratory

Richland, Washington 99352 


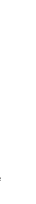




\section{PREFACE}

This is the ninth quarterly report for the project "Chemical Species of Migrating Radionuclides at Commercial Shallow Land Burial Sites" (NRC FIN B2291) under a reporting schedule initiated in mid-1982. The next report is scheduled in October, 1984.

The project task organization has undergone extensive revisions since this reporting schedule was established. To assist the reader to follow the progress of the research, as each new report is prepared we are summarizing previously reported research under a section titled "Summary of Prior Efforts."

Detailed reporting of research findings will continue to be published in quarterly, topical and annual reports and in the open literature. 


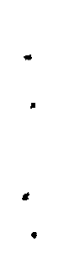




\section{EXECUTIVE SUMMARY}

The primary purposes of this project are to develop an understanding of chemical processes that significantly influence the migration of radionuclides at commercial low-level waste (LLW) burial sites and to evaluate ecological field sampling procedures for monitoring the performance of these sites. This project will produce for the U.S. Nuclear Regulatory Commission (NRC) information to support guidance for implementation of 10 CFR 61, particularly in the development of criteria for LLW disposal site selection, management, permanent closure and monitoring. This project will also produce information needed by the Commonwealth of Kentucky as they finalize plans to stabilize, close and monitor the Maxey Flats site.

- Chemical Forms: Inorganic and Organic Radionuclide Species

Comprehensive organic analyses performed on Maxey Flats waste trench leachates, water from the experimental trench and water from the inert atmosphere wells have determined a large number of hydrophilic and hydrophobic organic compounds in these waters. Analys is of the field-separated solutions from chromatographically fractionated water samples has revealed a complex pattern of association between radionuclides and organic compounds in these waters. Ethylenediaminetetraacetic acid (EDTA) is a major organic compound in waste trench leachates and in water from inert atmosphere well W2NA and evidence points to the existence of plutonium within the site as an EDTA complex. Polar organic compounds (e.g. palmitic and stearic acids) are associated with ${ }^{90} \mathrm{Sr}$ and ${ }^{137} \mathrm{Cs}$ and may be involved in the migration of these radionuclides.

Six classes of hydrophilic organic compounds are present in the waste trench leachates: synthetic chelating agents containing ethylenediamine as a core; dicarboxylic acids; monocarboxylic acids; oxygenated carboxylic acids; aromatic carboxylic acids; and phthalic acid esters. The chelating agents are typically used in decontamination operations at nuclear facilities. The four classes of carboxylic acids are common bioorganic compounds or their degradation products. 
Phthalates are used in industry as plasticizers and may also be microbial diagenes is products.

The most abundant hydrophilic organic compounds identified in the waste trench leachates are the chelating agents, ranging from 22.9 $\mathrm{ppm}$ in trench $19 \mathrm{~W}$ down to $0.08 \mathrm{ppm}$ in waste trench $33 \mathrm{~L}-8$. Three chelating agents were identified in the leachates: EDTA, $\mathrm{N}$ - hydroxyethylethylenediaminetriacetic acid (HEDTA), and ethylenediaminetriacetic acid (ED3A). EDTA is common to all of the leachates over a wide range of concentrations, ranging from 12.4 ppm in trench $19 \mathrm{~W}$ down to $0.08 \mathrm{ppm}$ in trench $33 \mathrm{~L}-8$. EDTA is the most abundant chelating agent in the leachates, with the exception of trench 23M where HEDTA is most abundant. The relative abundance of EDTA in the leachates varies considerably: it constitutes $81 \%$ of the chelating agent pool in trench $7-3$; $54 \%$ in trench $19 \mathrm{~W} ; 71 \%$ in trench $19 \mathrm{~S}$; a low $17.3 \%$ in trench $23 \mathrm{M}$; $82 \%$ in trench 27 ; and $100 \%$ in trenches $33 \mathrm{~L}-4$, $33 \mathrm{~L}-8$ and 35 . These differences undoubtedly reflect differences in the wastes originally buried, as well as differences in the microbial and chemical environments of the waste trenches.

Overall, HEDTA is the second most abundant chelating agent in the waste trenches. In trench 23M it is the most abundant hydrophilic organic compound at $19.5 \mathrm{ppm}$. This value is the highest for any of the chelating agents. An unusually high concentration of ED3A is also present in waste trench $23 \mathrm{M}$ and may be derived from the degradation of HEDTA.

Analys is of the hydrophobic organic compounds that were isolated to facilitate the chromatographic analys is of hydrophilic organic species has also permitted us to obtain information on toxic organic compounds that are present in these waters. The hydrophobic organic compounds identified in the waste leachates from Maxey Flats are generally at much lower concentrations than those of the hydrophilic organic compounds (ppb vs ppm). A number of the compounds, e.g., the halogenated hydrocarbons, are toxic and, therefore, of potential environmental concern. Their concentrations are quite low, however. 
In this research, some of the hydrophobic organic compounds, (e.g., the barbiturates), have been exploited as in situ waste-derived tracers of groundwater flow.

- Subsurface Migration and Infiltration Studies

Well-logging measurements of inert atmosphere wells, experimental trench sumps, and three four-inch diameter E-series wells on and near the site have confirmed that waste radionuclide migration along the sandstone marker bed could only be detected at one location within the restricted area at Maxey Flats. Cesium-137 (0.84 pCi/gm) and ${ }^{60}$ Co $(0.54 \mathrm{pCi} / \mathrm{gm})$ were measured in well $14 \mathrm{E}$ on the Maxey Flats site at the top of the sandstone marker bed, or about 6.1 meters (20 feet) below the ground surface. Strontium-90 is also present at or below the detection limit ( $10 \mathrm{pCi} / \mathrm{gm}$ or less).

Analys is of composited water samples from selected E-series wells around the Maxey Flats site has revealed that only tritium is present in significant quantities; ${ }^{60} \mathrm{Co},{ }^{0} \mathrm{Sr},{ }^{137} \mathrm{Cs}, 238,239 \mathrm{Pu}$ and $241_{\mathrm{Am}}$, as well as other radionuclides specifically mentioned in 10 CFR 61 (e.g., ${ }^{14} \mathrm{C},{ }^{59} \mathrm{Ni}, 63_{\mathrm{Ni}},{ }^{99} \mathrm{TC},{ }^{129} \mathrm{I}$ ), were not detectable in these samples. These measurements verify that subsurface migration of radionuclides has occurred over limited distances within the Maxey Flats restricted area, but with the possible exception of tritium, subsurface migration to points outside the restricted area has not been a significant source of contamination by radionuclides of the environs adjacent to the Maxey Flats site.

- Ecological Monitoring at Commercial Shallow Land Burial Sites

Ecological field sampling performed at Maxey Flats has evaluated a broad spectrum of radionuclides in leaves, forest floor litter and surface soil but only ${ }^{3} \mathrm{H}$ and ${ }^{60} \mathrm{Co}$ appear to be derived from the disposal site. Even these radionuclides are at only slightly elevated levels, well below the MPC's for drinking water. These surveys indicate that leaf fall can be a cost-effective, efficient way to estimate the annual contribution of radionuclides to the forest floor of oak-hickory forests. Tree sap and water from transpiring leaves have 
also been collected and analyzed for tritium. The results demonstrate that tritium uptake by deeprooted trees has potential to serve as a biomonitor of subsurface movement of water from burial sites and that biomonitors are useful for evaluating radionuclide migration from shallow land burial sites. Intensive tree leaf sampling around the Maxey Flats site has also demonstrated how the data may be used to establish locations for sampling wells in optimum positions for the detection of potential radionuclide migration.

During the previous quarter extensive sap sampling was conducted in the forest surrounding the Maxey Flats site. Tritium concentrations in the sap water were substantially lower than similar samples analyzed in early 1983, reflecting the effect of prolonged shutdown of the evaporator on tritium levels in the environment. During the reporting quarter leaf sampling was conducted in the forest surrounding the Maxey Flats site prior to the resumption of evaporator operation. The samples obtained are possibly the last set that will not have been influenced by contemporary evaporator operation. Eight of the trees reflected increased tritium levels over 1983, attributable to sources other than the evaporator. Six of the trees reflected decreased tritium levels over 1983, as would be expected if the evaporator had been the primary influence on their tritium levels. Three of the trees that were highest in 1983 were also highest in 1984 and probably derived their tritium from a subsurface source. No other radionuclides in these trees appear to have been influenced by the site.

- Technical Program Coordination

The report PNL-4432-8, "Chemical Species of Migrating Radionuclides at Commercial Shallow Land Burial Sites, Quarterly Progress Report, January-March, 1984" was published and distributed in Apri 1, 1984. 


\section{TABLE OF CONTENTS}

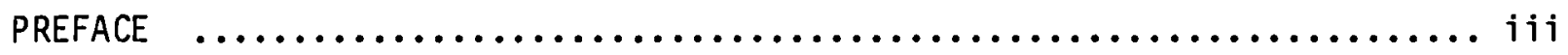

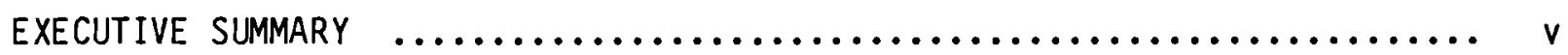

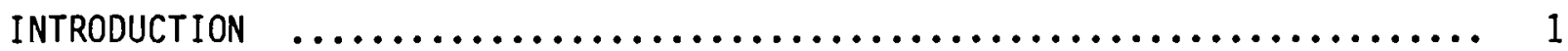

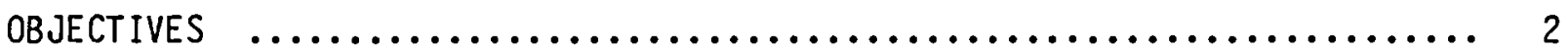

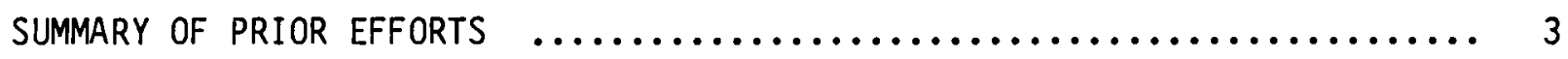

SIGNIFICANT CURRENT RESEARCH RESULTS $\ldots \ldots \ldots \ldots \ldots \ldots \ldots \ldots \ldots \ldots \ldots \ldots, 9$

Task A - Chemical Forms: Inorganic and Organic

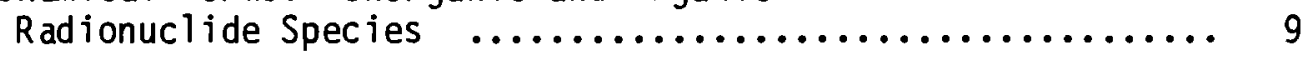

Task B - Subsurface Migration and Infiltration

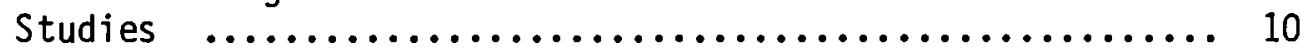

Task C - Specific Radionuclide Mapping at Maxey Flats and Other Commercial Shallow Land Burial Sites ................. 11

Task D - Ecological Monitoring at Commercial Shallow Land

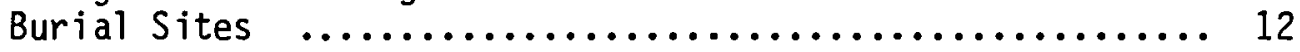

Task E - Technical Program Coordination for Low-Level

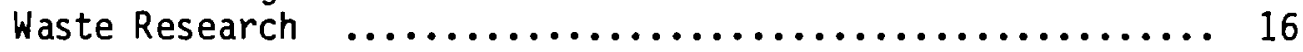

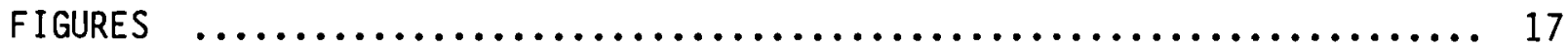

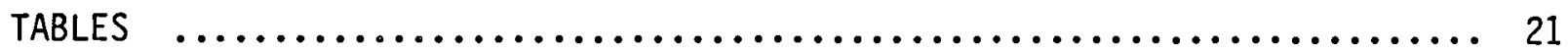

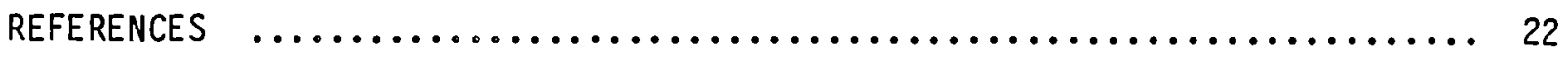




\section{INTRODUCTION}

One of the most important factors to be considered during the long-term isolation of radioactive wastes at commercial LLW shallow land burial sites is the subsurface migration of radionuclides, which depends, among other things, on the chemical forms of the radionuclides. The oxidation state, ionic form, and the formation of complexes or chelates with organic ligands can markedly influence radionuclide migration. Therefore, determination of the precise chemical species of radionuclides that have migrated is essential for an accurate evaluation of the long-term performance of shallow land burial sites. It is also essential to identify the organic and inorganic compounds and ionic species which are present in buried waste or can be generated in situ by chemical reactions and subsequently participate in the formation of the chemical species that may be shown to migrate.

Pacific Northwest Laboratory (PNL) has assisted in coordinating the NRC research program at Maxey Flats since 1979 to establish and carry out a unified and comprehensive study of the problems specific to that site and to obtain generic information that may be useful in setting criteria for decomissioning of existing commercial sites and for licensing of future commercial LLW burial sites. The objectives of this broad, multidisciplinary, multilaboratory program have included determining:

- Radiochemical and chemical composition of leachates in waste burial trenches;

- Subsurface migration rates of radionuclides and the chenical, physical, biological, and hydrogeological factors which affect this migration;

- Areal distribution of radionuclides at commercial shallow land burial sites and the factors responsible for this distribution;

- Concentrations of radionuclides in vegetation both on and off site and the uptake of radionuclides by representative agricultural crops;

- Atmospheric pathways for radionuclide transport and the mechanisms involved; and

- Engineering practices which influence the seepage of surface waters into the burial trenches. 


\section{OBJECTIVES}

The primary purposes of this project are to develop an understanding of the chemical processes that influence radionuclide migration at commercial LLW burial sites and to evaluate ecological field sampling procedures for monitoring the performance of these sites. This project will produce for NRC information to support guidance for implementation of 10 CFR 61, particularly in the development of criteria for commercial LLW disposal site selection, management, permanent closure and monitoring.

Specific objectives of this project with respect to measurements to be made at existing sites are:

- Define the actual chemical species of the radionuclides which are migrating by subsurface routes;

- Identify the chemical characteristics of the trench leachate which retard or enhance radionuclide mobility;

- Determine the chemical changes in leachate properties which result from installation of infiltration barriers such as the flexible vinyl covers at Maxey Flats;

- Provide the chemical and radiochemical input parameters essential for hydrological/geochemical modeling of subsurface radionuclide transport;

- Determine the factors responsible for the areal distributions of surface radionuclides and develop improved procedures for monitoring;

- Develop and test post-closure monitoring protocols that can be used at Maxey Flats and test the applicability of these protocols to operational and post-operational monitoring at other commercial sites; and

- Assist in coordinating LLW research projects for NRC.

Field measurements at shallow land burial sites provide unique opportunities to identify in actual waste burial situations the chemical and geochemical parameters which retard or enhance radionuclide mobility at LLW burial sites. The work at Maxey Flats also responds to the need for information on the areal 
distribution of radionuclides and the extent of subsurface transport of radionuclides at that site. This data base is needed by the Commonwealth of Kentucky as they finalize plans to stabilize, close and monitor the Maxey flats site.

\section{SUMMARY OF PRIOR EFFORTS}

Under this research program, PNL assists in coordinating NRC-sponsored LLW research, which has included PNL studies on chemical species and areal distributions of radionuclides, work on trench water chemistry by Brookhaven National Laboratory (BNL), plant uptake studies by the University of CaliforniaLos Angeles, engineering studies by the University of Arizona, unsaturated flow studies by Los Alamos National Laboratory (LANL) and The University of California - Berkeley (UCB), and water and mass balance studies by the Commonwealth of Kentucky.

To conduct experiments for determining the subsurface transport of radionuclides from existing waste burial trenches at a comercial LLW site, two experimental areas were established within the Maxey Flats, Kentucky, LLW disposal facility. This required the cooperation of several national and state agencies, together with the NRC contractors, for successful implementation. These experimental areas included:

- An experimental slit trench installed during the last quarter of FY 1979 and first quarter of FY 1980; and

- Fourteen inert atmosphere sampling wells installed in undisturbed soil adjacent to the experimental slit trench during the last quarter of FY 1980. A comprehensive array of porous cups and soil moisture cells was also installed for the LANL and UCB programs.

The experimental areas have been described in NUREG/CR-1832, Section IV and NUREG/CR-2383, Section I and are illustrated in Figures 1 and 2 of this report. These experimental areas have supported research studies by PNL, LANL, UCB and BNL. 
The two experimental areas have enabled samples to be taken for the study of chemical species of radionuclides, saturated and unsaturated flow, nonradioactive tracer movement, trench cap engineering and drainage, plant uptake, and total water balance by the laboratories participating in research at Maxey Flats. These experiments have provided needed information on rates and mechanisms of subsurface transport of radionuclides from waste burial trenches by both saturated and unsaturated flow at the Maxey Flats site.

Field measurements have been performed by PNL at the Beatty, Nevada(11), and Maxey Flats, Kentucky, (NUREG/CR-2383, Section II and NUREG/CR-1832, Section IV) burial sites to help determine the areal distribution of radionuclides at these sites and the factors responsible for this distribution. Field measurements were also performed adjacent to the Maxey Flats facility, and confirmed that contamination is largely contained within the restricted area at this burial site. The areal distribution of radionuclides at Maxey Flats has been influenced by site operation and maintenance activities, surface contanination and runoff, deposition from the evaporator plume, and the actions of burrowing animals or deep-rooted trees. Vegetational and surface contamination on site and near site are quite low; of the gamma-ray-emitting radionuclides measured, only 60 co exceeds commonly observed fallout levels. The average concentrations in surface soil at Maxey Flats are comparable to concentrations resulting from normal fallout in other areas of high rainfall. Tritium concentrations in water near the site have been influenced by surface runoff and by condensation from the evaporator plume.

Following analys is of trench leachates sampled in October, 1978 and November, 1979, Cleveland and Rees(10) concluded that except for leachate from waste trench 27 most of the plutonium in trench water is in true solution, in the tetravalent state, and exists in complexes with strong organic ligands. PNL research conducted in 1979 and 1980 (NUREG/CR-1832, Section IV) demonstrated that plutonium in water from the experimental trench and in waste trench 27 leachate was present in highly complexed, anionic, reduced (trivalent and tetravalent) species. EDTA is the major organic complexing component in waste trench 
27 leachate, but other polar, water-soluble organic compounds are also present (NUREG/CR-2383, Section I and NUREG/CR-3607, Section 1). Plutonium and EDTA co-elute during steric exclusion chromatography of Maxey Flats trench and well waters, and evidence points to the existence of plutonium within the site as an EDTA complex. Polar organic compounds (e.g. palmitic and stearic acids) are associated with $90 \mathrm{Sr}$ and $137 \mathrm{Cs}$ and may be involved in the migration of these radionuclides. These studies have demonstrated the need to determine the stability of the various chelates and complexes under the conditions existing in waste trench water at Maxey Flats, the conditions under which complexes of plutonium, americium, cobalt and strontium can be decomposed and/or sorbed on the geologic media, and the need to separate and measure the concentrations of hydrophilic organic complexing agents that may affect the migration of radionuclides present in waste trench leachate.

Three chelating agents - EDTA, HEDTA and ED3A - were identified in the waste trench leachates (3). EDTA is common to all of the leachates over a wide range of concentrations, ranging from $12.4 \mathrm{ppm}$ in trench $19 \mathrm{~W}$ down to $0.08 \mathrm{ppm}$ in trench $33 \mathrm{~L}-8$. EDTA is the most abundant chelating agent in the leachates, with the exception of trench 23M where HEDTA is most abundant. The relative abundance of EDTA in the leachates varies considerably: it constitutes $81 \%$ of the chelating agent pool in trench $7-3$ and only $17.3 \%$ in trench $23 \mathrm{M}$. The differences undoubtedly reflect differences in the wastes originally buried, as well as differences in the microbial and/or chemical environments of the waste trenches. Overall, HEDTA is the second most abundant chelating agent in the waste trenches. In trench $23 \mathrm{M}$ it is the most abundant hydrophilic organic compound at $19.5 \mathrm{ppm}$. This value is actually the highest for any of the chelating agents. This overabundance of HEDTA, coupled with the unusually high concentration of ED3A, suggests that the waste buried in trench $23 \mathrm{M}$ is different than that of most of the waste trenches. The third chelating agent identified in the waste leachates is ED3A. It is the least abundant of the three chelating agents and is presumably a degradation product of HEDTA or EDTA, since EDTA has been reported to undergo environmental degradation to ED3A(13). The absence of some of the chelating agents in certain leachates suggests differences in the waste originally buried or, perhaps, in the environment of the trenches. 
The other hydrophilic organic compounds consist of a variety of carboxylic acids. Collectively, the carboxylic acids range in concentration from $8.8 \mathrm{ppm}$ in trench 7-3 down to $0.7 \mathrm{ppm}$ in waste trench 27 . The dicarboxylic acids are the most abundant acids. One of these acids, oxalic acid, is used in nuclear decontamination operations but it is present only in leachate from waste trench 195 at a relatively low concentration of $0.1 \mathrm{ppm}$. Only two monocarboxylic acids were identified - hexadecanoic acid, commonly known as palmitic acid and octadecanoic acid, cormonly known as stearic acid. Groundwater samples typically contain these two compounds plus a variety of other monocarboxylic acids. The lack of monocarboxylic acids in the leachate samples undoubtedly reflects the fact that the water samples are relatively stagnant leachates of buried waste.

As a whole, the carboxylic acids are potential complexing agents of radionuclides, but any such association would be expected to be much weaker than the association of radionuclides and the chelating agents. However, these bioorganic acids could well constitute the precursors of fulvic and humic acids, which of ten comprise most of the bulk of the dissolved organic carbon (DOC) in groundwater and may be responsible for complexing radionuclides. The importance of such species to the complexation of radionuclides in groundwater is uncertain at this time, but should not be overlooked. Considerable research needs to be carried out on the role of the so-called "natural" organic compounds such as fulvic and humic acids in mobilizing or retarding radionuclide transport in soil solutions.

Comprehensive organic analyses performed on Maxey Flats waste trench leachate, water from the experimental trench and water from the inert atmosphere wells have determined a large number of hydrophobic organic compounds in these waters $(6)$. The concentrations of these compounds are generally much lower than those of the hydrophilic organic compounds (ppb vs ppm). Analys is of the hydrophobic organic compounds that were isolated to facilitate the chromatographic analys is of hydrophilic organic species has also permitted us to obtain information on toxic organic compounds that are present in these waters(5). A number of the compounds, e.g., the halogenated hydrocarbons, are toxic and of potential environmental concern. Their concentrations are quite low, however. Most of the hydrophobic organic compounds are present at parts-per-billion 
levels and only three of these compounds - pentafluorobenzoic acid (a nonradioactive tracer added to evaluate trench caps on the experimental trench), 2 (3H)-benzothiazolone (present in waste trench 27 leachate) and a group of alkylphenoxy oligomers (present in inert atmosphere well W2NA) - are present at parts-per-million levels. Two barbiturates, barbital and pentobarbital, were also identified in water samples from waste trench 27 and inert atmosphere we 11 W2NA. In this research, the barbiturates have been exploited as in situ waste-derived tracers of groundwater flow and the amount of information potentially available justifies the research effort in analyzing the hydrophobic organic compounds.

Changes in tritium concentrations in water from the experimental trench and in inert tracers (e.g., sodium bromide) which were added to the trench (NUREG/CR-1832, pages IV-10 and IX-6) confirm that subsurface flow does occur rather rapidly within the limited area of these experimental facilities. While increases in water level have occurred in the experimental trench, the absence of certain tracers in the water indicates that these increases have occurred without movement through the different trench caps installed on the five sections of the experimental trench (NUREG/CR-2383, Section I).

Ecological field sampling performed at Maxey Flats (NUREG/CR-1832, Section $V$, and NUREG/CR-2383, Section III) has evaluated a broad spectrum of radionuclides in leaves, forest floor litter and surface soil, but only $3 \mathrm{H}$ and $60 \mathrm{Co}$ appear to be derived from the disposal site. Even these radionuclides are at only slightly elevated levels and are comparable to ambient fallout levels. Collections of freshly fallen tree leaves indicate that leaf fall collection is a cost-effective, nondestructive sampling procedure that can be incorporated into ecological monitoring programs to indicate migration or lack of migration from shallow land disposal sites. Tree sap and water from transpiring leaves have been collected and analyzed for tritium, indicating that tritium uptake by deeprooted trees has potential to serve as a biomonitor of subsurface movement of water from burial sites. The field surveys have demonstrated that biomonitors are useful as indicators of radionuclide migration from shallow land burial sites. 
Carbon-14 analyses of wood from selected trees adjacent to the Maxey Flats restricted area were compared with analyses from tree specimens at a location 12 miles from the Maxey Flats Facility. These limited data suggested that the site may have influenced $14 \mathrm{C}$ levels very slightly at a few locations near the perimeter fence. The source of $14 \mathrm{C}$ in the wood specimens is from carbon dioxide that is assimilated from air in the photosynthesis process $(5)$.

Remaining important areas of research include the fate of mobile (possibly complexed) radionuclide species after leaving the trench environment, the control of these species within the commercial site boundaries, remedial action that can be taken to halt this mobility, and whether complexing agents such as EDTA can be effectively destroyed in an aerobic environment.

Important observations from research conducted by PNL at Maxey Flats include:

- Identification of the magnitude of transport over short distances within the burial site by subsurface flow;

- Characterization of some of the important chemical species including plutonium-EDTA complexes which influence subsurface migration;

- Identification of surface runoff from the site as a principal source for off-site radionuclide accumulation in vegetation;

- Determination of the off-site distribution of radionuclides at Beatty, Nevada, and Maxey Flats, Kentucky; and

- Establishment of the complexity and variability of waste trench leachates as source terms for the migration studies. (PNL research complements the comprehensive analyses performed on waste trench leachate by BNL. See, for example, NUREG/CR-2383, Section IV, and NUREG/CR1832, Section III.)

- Characterization of biomonitors as indicators of radionuclide migration and subsurface movement of water at shallow land burial sites. 
These research observations and related observations from the research performed at Maxey Flats by BNL, LANL, UCB, the University of Arizona and the University of California-Los Angeles are described in NUREG/CR-3607(2), NUREG/CR-2383(8) and NUREG/CR-1832(12).

\section{SIGNIFICANT CURRENT RESEARCH RESULTS}

This is the ninth quarterly report for the project "Chemical Species of Migrating Radionuclides at Commercial Shallow Land Burial Sites." The organization of these reports has undergone many changes since the first report was issued in order to conform to revised research proposal formats requested by NRC. Work on Task B was suspended during the first quarter of FY 1984 to permit the analysis of samples collected at Chalk River, Canada. Work on Tasks A and $C$ has also been suspended and FY 1984 research efforts are concentrated in Task D. We will continue to report and summarize research results by subject and task.

Task A - Chemical Forms: Inorganic and Organic Radionuclide Species

The migration rates of radionuclides depend to a major degree on their chemical species. It. is therefore extremely important to determine the chemical species in the waste burial trenches and in any water which has carried radionuclides to our sampling points in the experimental trench and inert atmosphere sampling wells, or to springs some distances from the waste-filled trenches. In this task we are determining as nearly as practicable the precise chemical forms for those radionuclides which are of greatest concern from an environmental and health standpoint. For example, plutonium is present at Maxey Flats in waste trench leachate as a reduced (trivalent and tetravalent), anionic, highly complexed species. Other prevalent radionuclides include $241_{\mathrm{Am}},{ }^{60} \mathrm{Co},{ }^{137} \mathrm{Cs}$ and $90 \mathrm{Sr}$, and possibly other radionuclides specifically mentioned in 10 CFR 61 (e.g., ${ }^{14} \mathrm{C},{ }^{59} \mathrm{Ni}, 61_{\mathrm{Ni}},{ }^{99} \mathrm{Tc},{ }^{129} \mathrm{I}$ ). The precise radiochemical and chemical parameters obtained from these studies will provide important basic information on the chemical species that develop under various burial conditions. In these studies we have supplemented our laboratory work with on-site chemical separa- 
tions employing tracers and organic ligand separations to minimize solution degradation and thereby duplicate as closely as possible actual field conditions.

The detailed chemical speciation studies have demonstrated that EDTA is co-eluting with plutonium and 60 Co during steric exclusion chromatography of water from waste trenches 27 and 195 and inert atmosphere well W2NA. Strontium-90 and $137 \mathrm{Cs}$ also appear to be associated with polar organic compounds, notably palmitic (hexadecanoic) and stearic (octadecanoic) acids. Quantitation of EDTA and of radionuclides in the concentrated and fractionated samples has demonstrated that the soluble plutonium is associated with EDTA.

Some of the plutonium originally present in the water samples is removed from the water during concentration of the samples by co-precipitation with iron. This occurs due to exposure to traces of oxygen or because the solubility limits for iron have been exceeded in the concentrated samples. This observation suggests that uncomplexed plutonium will be fixed to the soil with the iron hydroxide precipitate when the anoxic groundwater is exposed to oxidizing conditions.

Task B - Subsurface Migration and Infiltration Studies

The experimental trench and wells study was undertaken to determine if subsurface migration of radionuclides had occurred at Maxey Flats, to measure the extent of any such migration, and to define the processes by which movement occurs. The work has utilized the experimental installations we established on the Maxey Flats site for defining migration rates and specific chemical species of long-lived fission products and the transuranium elements. It is also allowing the determination of the chemical species of migrating nonradioactive elements associated with waste and utilizes nonradioactive tracer movement to evaluate the effects of engineered trench caps and drainage systems on water infiltration rates.

Most samples from the porous cups, experimental trench sumps and inert atmosphere wells (Figure 2) have been collected on a monthly frequency, weather and water levels permitting. The water samples have been analyzed for $3 \mathrm{H}$, gamma-ray emitting radionuclides (e.g., ${ }^{60} \mathrm{Co},{ }^{137} \mathrm{Cs}$ ), alpha-emitting radio- 
nuclides (e.g., 238,239,240 Pu, 241Am), hydrophilic and hydrophobic organic species, and nonradioactive elements that can be determined by neutron activation (e.g., $\mathrm{Br}$ ). These measurements verify that within the Maxey Flats restricted area subsurface migration of radionuclides has occurred over limited distances (NUREG/CR-2383, page I-13). Except for tritium, migration to points outside the restricted area has not been a significant source of contamination by radionuclides.

We1l-logging of the inert atmosphere wells and experimental trench sumps (Figure 2) and of selected E-series wells (Figure 3 ) at Maxey Flats has confirmed that waste radionuclide migration along the sandstone marker bed occurred only within the restricted area. Cesium-137 (0.84 pCi/gm of soil) and $60 \mathrm{Co}_{0}$ (0.54 $\mathrm{pCi} / \mathrm{gm}$ of soil) were measured in well $14 \mathrm{E}$ on the Maxey Flats site at the top of the sandstone marker bed, or about 6.1 meters (20 feet) below the ground surface. The concentrations observed are below the concentrations measured in surface distribution studies (NUREG/CR-2383, Section II and NUREG/CR-1832, Section IV). Naturally-occurring radionuclides quantified included 226Ra (0.99 $\mathrm{pCi} / \mathrm{gm}),{ }^{232} \mathrm{Th}(1.2 \mathrm{pCi} / \mathrm{gm})$ and $40 \mathrm{~K}(10 \mathrm{pCi} / \mathrm{gm})$. Strontium-90 is also present at or below the detection limit by well-logging techniques ( $<10 \mathrm{pCi} / \mathrm{gm}$ of soil). We are continuing our efforts to quantify the ${ }^{90} \mathrm{Sr}$ concentration at this location.

Task C - Specific Radionucl ide Mapping at Maxey Flats and Other Commercial Shallow Land Burial Sites

The Maxey Flats burial site has been contaminated by several sources. These include the overflow of water from the burial trenches as rainwater infiltrated and filled them, spillage during pumping of excess water from the trenches, fallout from entrained radionuclides in the evaporator plume, and surface runoff of radioactive solutions from the site. To obtain a better understanding of the actual sources of radioactivity in surface soils and vegetation on the burial sites and adjacent areas, a detailed study of the levels of radioactivity has been underway at Maxey Flats and related studies should also be useful at other commercial shallow land burial sites. 
In situ gamma ray surveys conducted at the Beatty, Nevada(11) and Maxey Flats, Kentucky (NUREG/CR-2383, Section II and NUREG/CR-1832, Section IV) shallow land burial sites confirmed that most of the waste radionuclides have been retained within the boundaries of those sites. The in situ measurements were correlated with and augmented by analys is of samples taken from each of the counting locations, since only the more energetic gamma ray emitting radionuclides are measured by the in situ procedures.

Slightly elevated tritium concentrations in water samples from springs and seeps outside the Maxey Flats restricted area suggested that other radionuclides might also be slightly elevated at these locations. However, all gamma-ray measurements have indicated that $60 \mathrm{Co}$ and $137 \mathrm{Cs}$ are present at ambient fallout levels. Strontium-90 and 238, 239, 240pu were also at ambient fallout levels, as determined from radiochemical separation and analysis of aliquots of soil and water. The measurements indicate that radionuclide migration to these springs and seeps is not occurring, except possibly for tritium.

These studies have demonstrated that surface contamination by radionuclides has been retained mainly within the restricted area at Maxey Flats. Surface sediments in areas adjacent to the site, primarily on the west side, contain $60 \mathrm{Co}$ in concentrations greater than fallout. The origin of the $60 \mathrm{Co}$ is from surface runoff into the adjacent woods. Measurements made to date indicate that offsite contamination has not resulted from subsurface transport, except possibly for tritium. The relative contributions of tritium from air (evaporator output), surface and subsurface pathways are being further evaluated prior to the resumption of evaporator use by the Commonwealth of Kentucky.

Task D - Ecological Monitoring at Commercial Shallow Land Burial Sites

In this task we are developing efficient and statistically valid ecological field sampling procedures and methods for post-closure monitoring at shallow land burial sites. Kinds and amounts of radionuclides and trace elements in environmental samples are being measured with emphasis on biotic uptake, bioaccumulation, biotic transport, and ecological pathways in semi-wild ecosystems. 
We are emphasizing the sampling for pattern approach to provide three dimensional data that are amenable to rigid statistical analysis.

Forest sampling at Maxey Flats indicates the presence of a broad spectrum of naturally occurring and fallout-derived radionuclides in the litter layers, surface soil, and in freshly fallen autumn leaves(9). Autumn leaf-fall samples were collected from the $0.5 \mathrm{~m}^{2}$ rectangular wire baskets $\mathrm{placed}$ beneath the permanently tagged trees adjacent to the Maxey Flats restricted area. These samples were dried and shipped to our PNL facilities at Richland, Washington, for analys is by gamma-ray spectrometry. We have determined the exogenous radionuclides (e.g., $60 \mathrm{Co}, 137 \mathrm{Cs}$ ) and obtained information on endogeneous (e.g., $7 \mathrm{Be}$, $40 \mathrm{~K}, 226 \mathrm{Ra}, 228 \mathrm{Th}$ ) radionuclides in the samples. Radiochemical analyses of gamma-ray emitting radionuclides show very low levels of all radionuclides and only ${ }^{60}$ Co was elevated above ambient fallout levels and is most likely of disposal site origin. Comparison of the radionuclide concentrations determined from several sampling runs (NUREG/CR-2383, Section III, and NUREG/CR-1832, Section $V$ ) indicates that except for ${ }^{60} C_{0}$ and tritium buried waste radionuclides have not migrated into the forest adjacent to the Maxey Flats site.

Tree sap and water from transpiring leaves have also been collected and analyzed for tritium to determine the degree to which tritium uptake by deeprooted trees has potential to serve as a biomonitor of subsurface movement of water from burial sites. Tritium is environmentally one of the most mobile of radionuclides and it can move as tritiated water, as vapor, or in surface or groundwater flows. Trees obtain water from their rooting substrate and move it from roots to stems to leaves, and release water to air as vapor. Water can be extracted from fresh tree leaves and analyzed for tritium. If tritium is present in the root zone, it appears in the extracted water. Because trees have deeply penetrating roots, as compared to crop plants, they can be used to monitor subsurface water flows.

Maple trees, Acer sacharum, have the unusual ability to move water through their trunk before new leaves emerge in the spring. If maple tree roots have access to tritiated water, tritium will appear in the sap stream. Maple trees have been tapped at more than 50 locations around the Maxey Flats disposal site and several trees have been tapped at a control location in a similar 
forest type near Cave Run Lake, about 12 miles south of Maxey Flats. Tritium concentrations in tree sap in 1983 ranged from below detection level to 290 $\mathrm{pCi}$ per $\mathrm{ml}$ of tree sap. The highest values occurred in two trees located along the western side of the disposal site and the lowest values were measured near Cave Run Lake, which represented fallout (background) tritium levels. Trees sampled in the vicinity of the disposal site generally had tritium levels higher than fallout levels, with the highest concentrations being measured on the steep slope bordering the western side of the disposal site. In general, tritium values declined with increasing distance from the disposal site.

Comprehensive tree leaf sampling has also been made to evaluate the feasibility of using extractable leaf water from tree species other than maple as an indicator of tritium migration. In addition to the trees sampled around the fence, transects have also been made from the fence westerly into orip Springs Hollow. Background samples were taken near Cave Run Lake, about 12 miles south of the Maxey Flats facility. Leaf water data indicate that tritium in above ambient fallout levels is present within the edge of the forest at Maxey Flats $(4,7)$. The leaf water data have provided a mechanism to evaluate the effect of prolonged evaporator shutdown on tritium distribution around the Maxey flats site and delineate regions where the primary source of tritium has been by subsurface flow.

Two trees sampled along the transect into Drip Springs Hollow contained much higher than normal concentrations of tritium (up to 27,000 pCi per ml). Other trees near this location 50 meters downslope from the fenced area contained substantially lower tritium concentrations, indicating that the source of tritium tapped by these trees is highly localized. These trees may pinpoint an ideal location to establish a set of monitoring wells outside the restricted area at Maxey Flats to monitor subsurface water for possible radionuclide migration.

Research in FY 1984 is emphasizing the assessment of field sampling procedures for monitoring the performance of LLW burial sites. The studies are designed to identify the components of an ecological system that are the more effective biomonitors and assess the sample collection frequency and intensity needed to detect contamination derived from a shallow land burial facility. 
We expect to determine the ecological pathway by which contaminants may be transported beyond a site, determine whether subsurface transport of contaminants can be detected using deep-rooted vegetation as biomonitors and evaluate the effect of seasonal and environmental cycles on contaminant movement.

During the previous quarter extensive sap sampling was performed around the Maxey Flats facility to evaluate the potential migration of tritium and other radionuclides from the site and determine the effect of the prolonged evaporator shutdown on tritium concentrations in the environs of the site. Tritium concentrations in maple sap collected in March, 1984 were generally significantly lower than similar concentrations of the preceding year, averaging $140 \mathrm{pCi} / \mathrm{ml}$ in 1983 and $22 \mathrm{pCi} / \mathrm{ml}$ in 1984. Tritium concentrations are presently about 60 times the background levels measured at Cave Run Lake, about 12 miles south of the Maxey Flats facility. The decline in tritium concentrations during the year was about six-fold due to the prolonged evaporator shutdown. (1)

During the reporting quarter leaf sampling was conducted in the forest surrounding the Maxey Flats site prior to the resumption of evaporator operation. Leaf sampling was not as extensive as that performed during earlier years because of the late start of leaf growth at the site and the need to resume evaporator operation at the site. Through the kind cooperation of the Kentucky Department for Natural Resources and Environmental Protection, resumption of evaporator operation was delayed sufficiently to permit an adequate set of samples to be obtained. This may represent the last set of samples obtainable at the site that will not have been influenced by contemporary evaporator operation. The leaf sampling locations for the May, 1984 sampling trip are summarized in Figure 4.

Tritium concentrations in leaf water from tree leaves collected along the western fence-line of the Maxey Flats restricted area in May, 1984 are compared with concentrations from July, 1983 in Table 1. Eight of the trees reflected increased tritium levels over 1983 suggesting that these trees obtain tritium from sources other than the evaporator, which was not operating during this time interval. Six of the trees reflected decreased tritium levels over 1983, which would be expected if the evaporator had been the primary source of tritium for these trees. However, two of these six trees - 055 and 097 - while showing significant decreases in tritium levels are never-the-less quite high when 
compared with the other trees and probably obtain most of their tritium from a highly localized subsurface source.

Additional trees were sampled to help evaluate the substantially elevated tritium levels in trees 055 and 097 . Tree 097E, about six meters east and slightly uphill from tree 097, also appears to obtain its tritium from the same highly localized subsurface source. Trees 0975 and 098 , about three meters from 097 , have obviously not tapped the same tritium source. To determine whether any of these trees would contain elevated levels of other waste radionuclides, additional analyses were performed. Gamma-ray spectrometric analysis of the leaf samples confirmed that uptake of gamma-emitting radionuclides from the site has been virtually non-existent. Destructive analys is of leaf sample aliquots confirmed that $90 \mathrm{Sr}$ was present at levels comparable to ambient (fallout) levels, and therefore not elevated through access to buried $90 \mathrm{Sr}$ containing wastes or leachates.

These measurements demonstrate the utility of tritium analys is as an early warning device to detect radionuclide migration from mixed radioactive wastes. Leaf sampling is a cost-effective sampling procedure that should be incorporated into ecological monitoring programs to indicate migration or lack of migration for LLW burial sites.

\section{Task E - Technical Program Coordination for Low-Level Waste Research}

The report PNL-4432-8, "Chemical Species of Migrating Radionuclides at Commercial Shallow Land Burial Sites, Quarterly Progress Report, JanuaryMarch, 1984" was published and distributed in Apri1, 1984. 


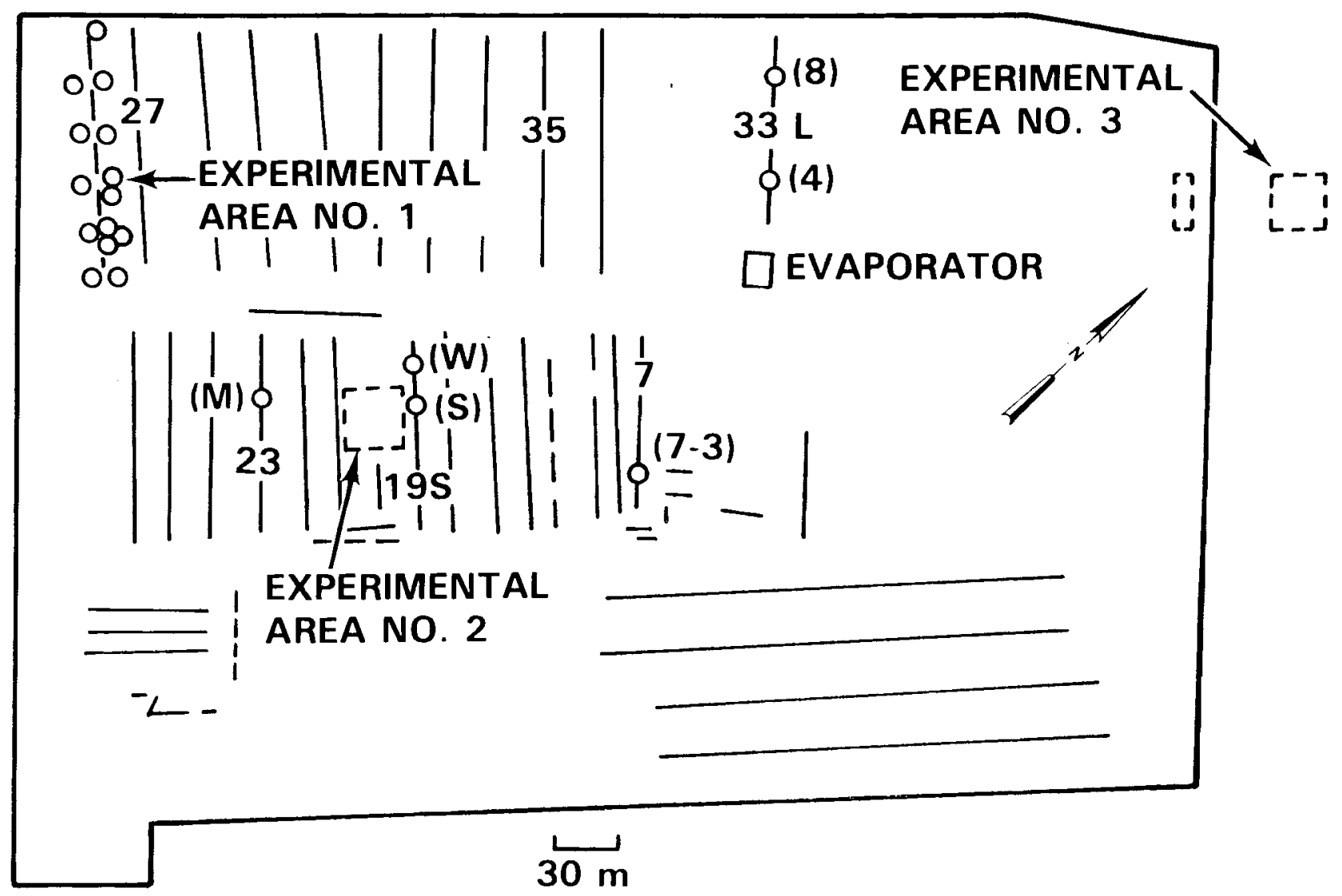

FIGURE 1. Maxey Flats waste trenches and experimental areas. The numbered lines show the locations of selected waste trenches and numbers and letters in parentheses indicate the locations of sumps. Experimental area number 1 includes the experimental trench and inert atmosphere wells. Experimental area number 2 includes the porous cup and tensiometer installations for studying water movement in the burial area. Experimental area number 3 includes the UCB lysimeter installations for water balance studies. These experimental areas support research studies by PNL, LANL. UCB and ENL. 


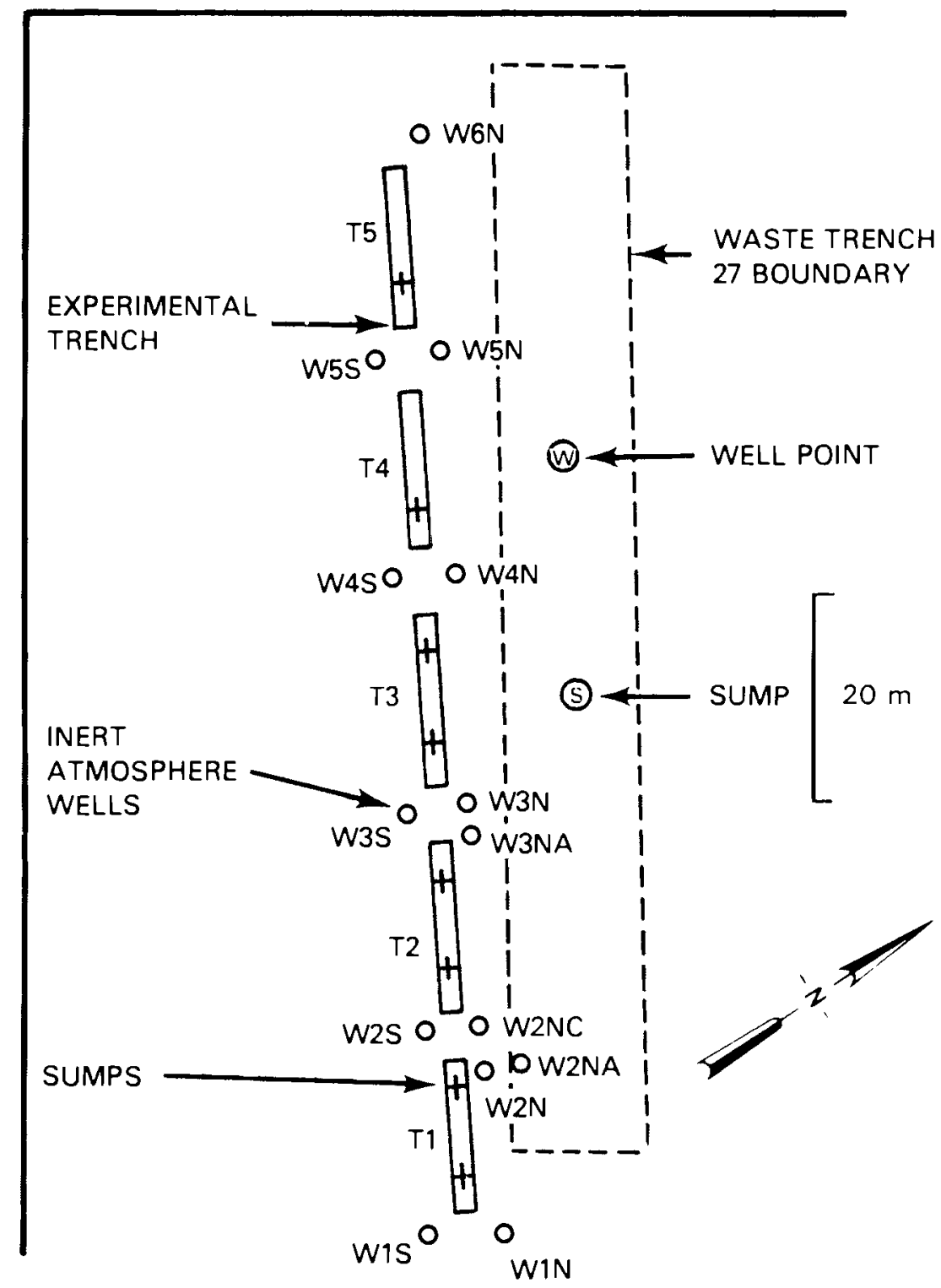

FIGURE 2. Maxey Flats Experimental Area No. 1, containing the experimental trench and wells near waste trench 27 . These facilities allow concurrent sampling of the experimental trench, inert atmosphere wells and adjoining waste trench for PNL groundwater migration and chemical species studies. The experimental trench is also used by LANL. UCB, and BNL in research studies at the Maxey Flats Shallow Land Burial Site. 


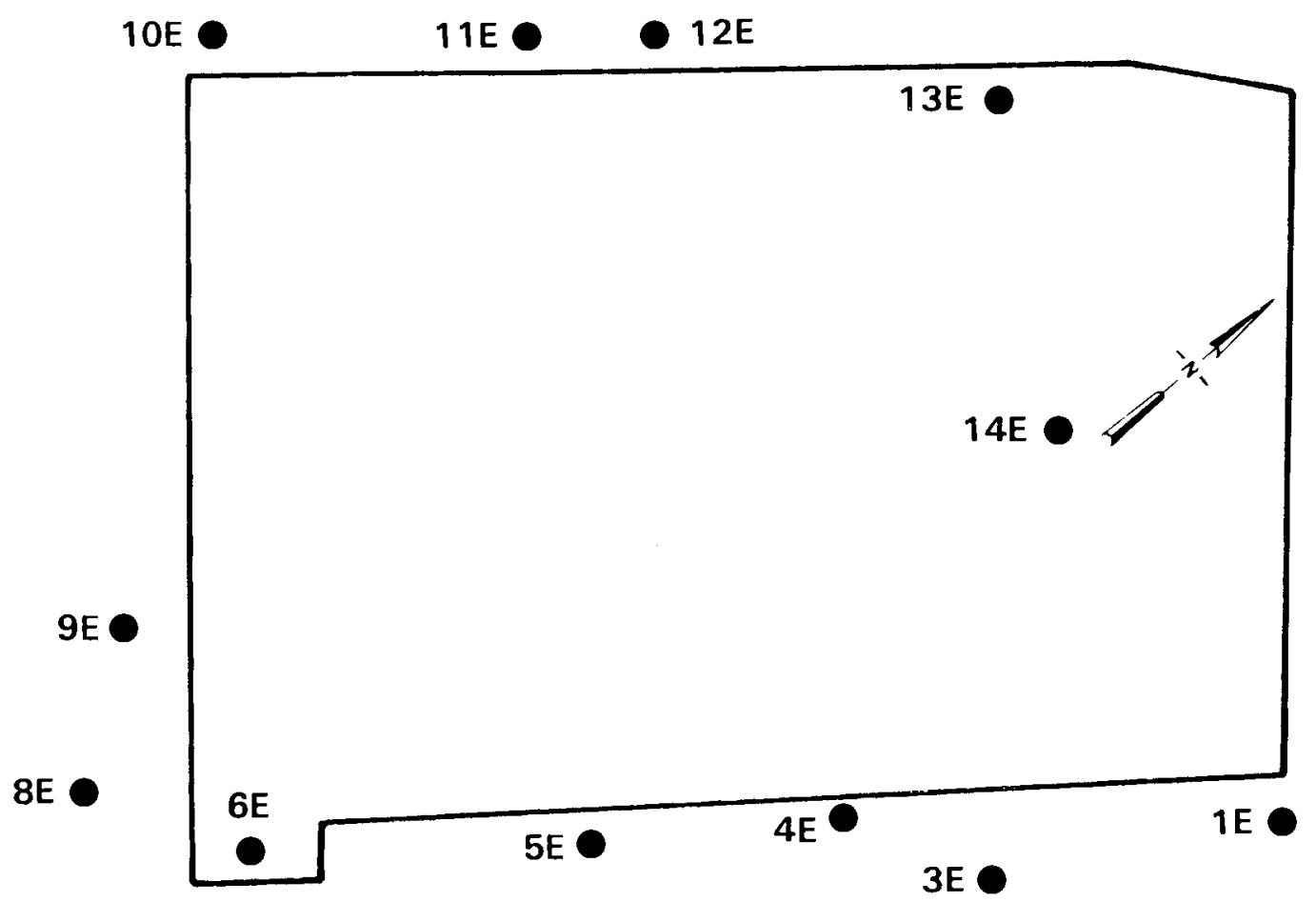

FIGURE 3. Locations of the E-series wells around the Maxey Flats restricted area. Three four-inch diameter wells - 13E, $14 \mathrm{E}$ and $3 \mathrm{E}$ - were logged and only 14E showed evidence of the presence of waste-derived radionuclides, e.g. ${ }^{137} \mathrm{Cs},{ }^{60} \mathrm{Co}$ and ${ }^{90} \mathrm{Sr}$. These radionuclides had migrated short distances within the restricted area along the sandstone marker bed. 


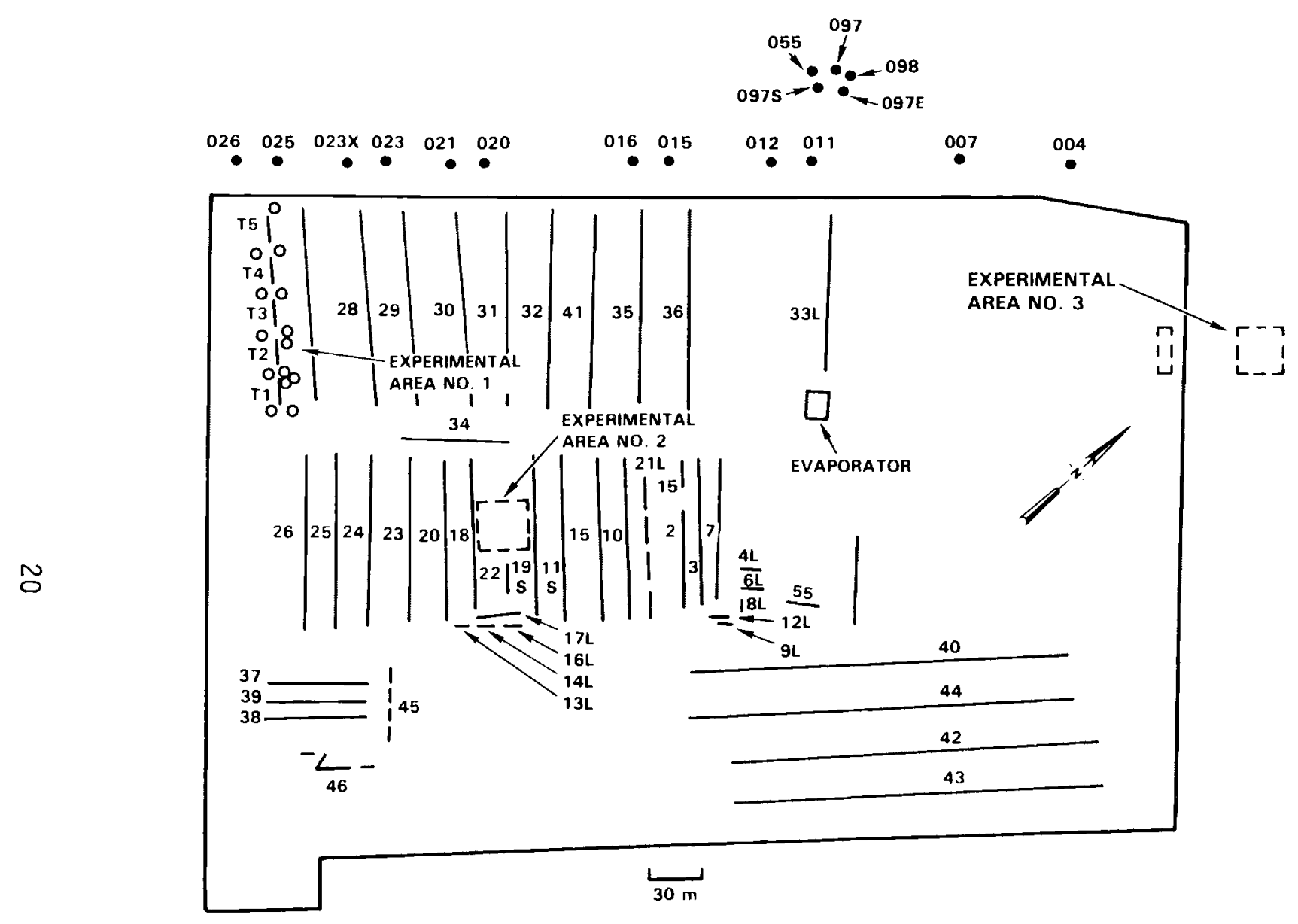

FIGURE 4. Locations of trees sampled for leaf water near the Maxey Flats Disposal Facility, May, 1984. Eight of the trees showed increases in tritium concentrations over 1983 and six of the trees showed decreases in tritium concentrations over 1983. Trees 055, 097 and 097E have much higher tritium concentrations than the other trees and probably are in contact with a highly localized source of tritium. 
Table 1. Tritium concentrations in leaf water from tree leaves collected along the western fence-line at the Maxey Flats waste disposal site in May, 1984. Concentrations are compared with concentrations measured in 1983 (picocuries per ml of distilled leaf water).

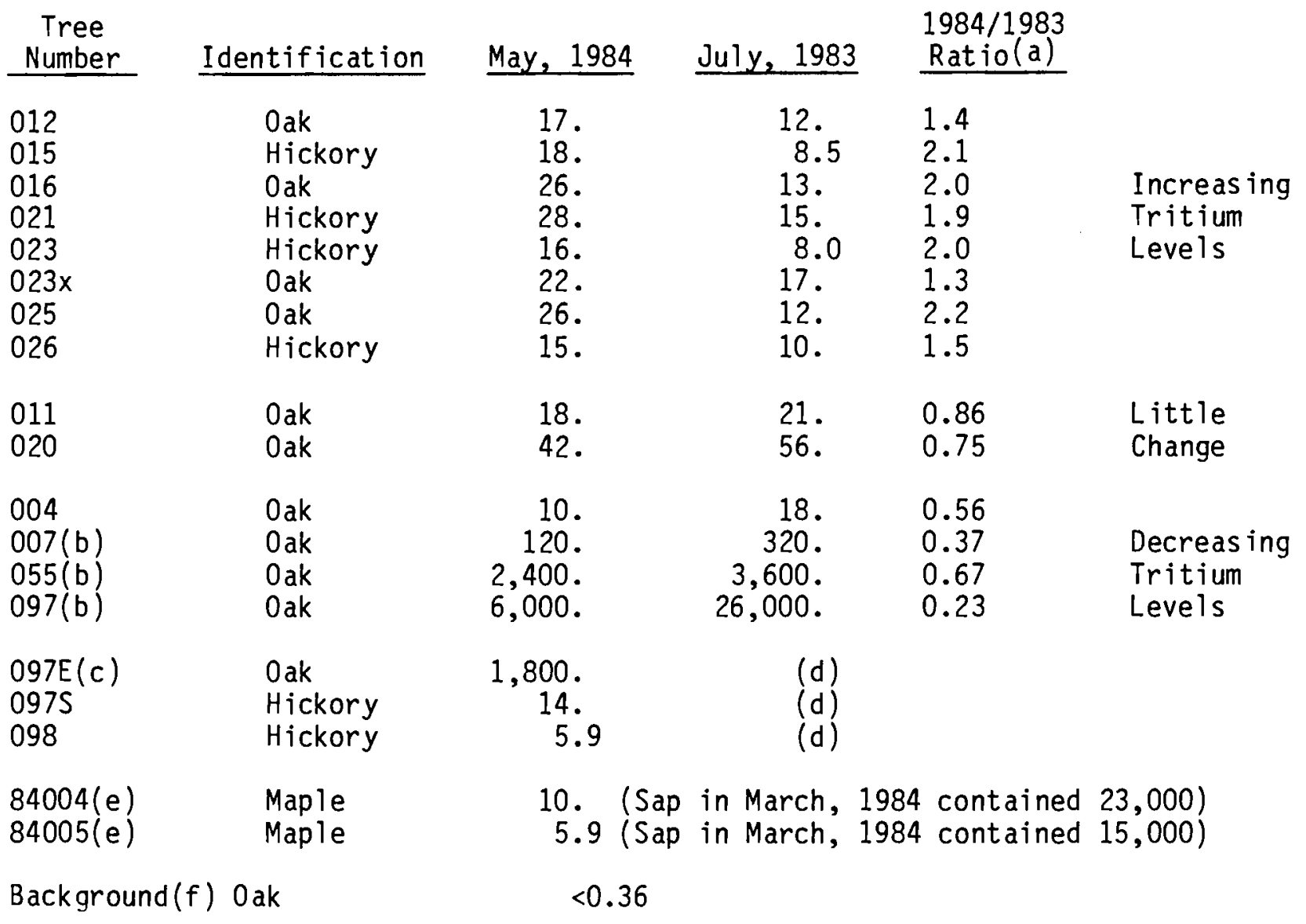

(a) Eight trees showed an increase in tritium concentrations between 1983 and 1984, two trees showed little change and four trees showed a definite decrease.

(b) Trees with the highest tritium concentrations in 1983 were also the highest in 1984 (007, 055 and 097).

(c) One oak tree - number 097E located 6 meters from tree 097 - had a greatly elevated level of tritium, indicating a subterranean source of tritium, as did 055 and 097.

(d) Trees 097E, $097 \mathrm{~S}$ and 098 were not sampled in 1983.

(e) Maple trees 84004 and 84005 had higher concentrations of tritium in sap collected in March, 1984 than in leaf water collected in May, 1984.

(f) Leaf water from a tree sampled at Cave Run Lake had background levels of tritium, or $<0.36 \mathrm{pCi} / \mathrm{ml}$. 


\section{REFERENCES}

1. L. J. Kirby, W. H. Rickard and A. P. Toste, "Chemical Species of Migrating Radionuclides at Commercial Shallow Land Burial Sites, Quarterly Progress Report, January-March, 1984," PNL-4432-8, April, 1984.

2. L. J. Kirby, Ed., "Radionuclide Distributions and Migration Mechanisms at Shallow Land Burial Sites: 1982 Annual Report of Research Investigations on the Distribution, Migration and Containment of Radionuclides at Maxey Flats, Kentucky," NUREG/CR-3607, 1984.

3. L. J. Kirby, W. H. Rickard and A. P. Toste, "Chemical Species of Migrating Radionuclides at Commercial Shallow Land Burial Sites, Quarterly Progress Report, October-December, 1983", PNL-4432-7, February, 1984.

4. L. J. Kirby, W. H. Rickard and A. P. Toste, "Chemical Species of Migrating Radionuclides at Commercial Shallow Land Burial Sites, Quarterly Progress Report, July-September, 1983," PNL-4432-6, November, 1983.

5. L. J. Kirby, A. P. Toste and W. H. Rickard, "Chemical Species of Migrating Radionuclides at Commercial Shallow Land Burial Sites, Quarterly Progress Report, April-June, 1983," PNL-4432-5, July, 1983.

6. L. J. Kirby, W. H. Rickard and A. P. Toste, "Chemical Species of Migrating Radionuclides at Commercial Shallow Land Burial Sites, Quarterly Progress Report, January-March, 1983," PNL-4432-4, Apri 1, 1983.

7. L. J. Kirby, A. P. Toste and W. H. Rickard, "Chemical Species of Migrating Radionuclides at Commercial Shallow Land Burial Sites, Quarterly Progress Report, October-December, 1982," PNL-4432-3, March, 1983.

8. L. J. Kirby, Ed., "Radionuclide Distributions and Migration Mechanisms at Shallow Land Burial Sites: Annual Report of Research Investigations on the Distribution, Migration and Containment of Radionuclides at Maxey Flats, Kentucky," NUREG/CR-2383, 1982.

9. W. H. Rickard, L. J. Kirby and M. C. McShane, "Gamma Emitting Radionuclides in a Deciduous Forest Surrounding a Shallow Land Burial Site in the Eastern United States," IAEA-SM-257-67P, in Environmental Migration of Long-Lived Radionuclides, International Atomic Energy Agency, Vienna, pp. 509-516, 1982.

10. J. M. Cleveland and T. F. Rees, "Characterization of Plutonium in Maxey Flats Radioactive Trench Leachates," Science 112, 1506 (1981).

11. H. L. Nielson, N. A. Wogman and L. J. Kirby, "Field Survey of the Shallow Land Low-Level Radioactive Waste Burial Site Near Beatty, Nevada," in The State of Waste Isolation in the U.S. and Elsewhere, Advocacy Program and Public Communications, M. E. Wacks and R. G. Post, Eds., Volume 2, pp. $707-719,1981$. 
12. L. J. Kirby, Ed., "Research Program at Maxey Flats and Consideration of Other Shallow Land Burial Sites," NUREG/CR-1832, 1981.

13. H. B. Lockhart, Jr. and R. V. Blakely, "Aerobic Photodegradation of Fe(III)(Ethylenedianitri10) Tetraacetate (Ferric EDTA)", Environ. Sci. Tech. 58 (19), 1999 (1980). 


\section{DISTRIBUTION}

No. of

Copies

OFFSITE

7 E. O'Donnell

U.S. Nuclear Regulatory Commission

Office of Nuclear

Regulatory Research

Mail Stop 1130SS

Washington, D.C. 20555

F. J. Arsenault

U.S. Nuclear Regulatory Commis sion

Office of Nuclear Regulatory Research

Mail Stop 1130SS

Washington, D.C. 20555

P. A. Comella

U.S. Nuclear Regulatory Commission

Office of Nuclear Regulatory Research

Mail Stop 1130 SS

Washington, D.C. 20555

E. F. Conti

U.S. Nuclear Regulatory Commission

Office of Nuclear Regulatory Research

Mail Stop 1130 SS

Washington, D.C. 20555

M. J. Bell

U.S. Nuclear Regulatory Commission

Office of Nuclear Material Safety and Safeguards

Mail Stop 697SS

Washington, D.C. 20555
No. of

Copies

R. E. Browning

U.S. Nuclear Regulatory Commission

Office of Nuclear Material Safety and Safeguards

Mail Stop 697SS

Washington, D.C. 20555

L. B. Higginbotham

U.S. Nuclear Regulatory Commission

Office of Nuclear Material Safety and Safeguards

Mail Stop 697SS

Washington, D.C. 20555

K. Jackson

U.S. Nuclear Regulatory Commission

Office of Nuclear Material Safety and Safeguards

Mail Stop 697SS

Washington, D.C. 20555

P. Ohaus

U.S. Nuclear Regulatory Commission

Office of Nuclear Material Safety and Safeguards

Mail Stop 697SS

Washington, D.C. 20555

J. F. Kendig

U.S. Nuclear Regulatory Commission

Office of State Programs

Mail Stop AR5235

Washington, D.C. 20555 
PNL-4432-9

\section{DISTRIBUTION}

No. of

Copies

G. F. Birchard

U.S. Nuclear Regulatory Commission

Division of Safeguards, Fuel Cycle and Environmental Research

Mail Stop 1130 SS

Washington, D.C. 20555

D. H. Alexander

U.S. Nuclear Regulatory Commission

Division of Safeguards, Fuel

Cycle and Environmental Research

Mail Stop 1130SS

Washington, D.C. 20555

D. Brooks

U.S. Nuclear Regulatory Comm iss ion

Office of Nuclear Material Safety and Safeguards

Mail Stop 697SS

Washington, D.C. 20555

W. Kelly

U.S. Nuclear Regulatory Commission

Office of Nuclear Material Safety and Safeguards

Mail Stop 697SS

Washington, D.C. 20555

R. J. Starmer

U.S. Nuclear Regulatory Commission

Office of Nuclear Material Safety and Safeguards

Mail Stop 697SS

Washington, D.C. 20555
No. of

Copies

2 U.S. Nuclear Regulatory Commission

Division of Technical Information and Document Control

7920 Norfolk Avenue

Bethesda, MD 20014

Document Control Center

U.S. Nuclear Regulatory Commission

Office of Nuclear Material Safety and Safeguards

Mail Stop 697SS

Washington, D.C. 20555

2 DOE Technical Information Center

P.0. Box 62

0ak Ridge, TN 37830

M. J. Barainca

U.S. Department of Energy

550 Second Street

Idaho Falls, ID 83401

E. A. Jennrich

U.S. Department of Energy

550 Second Street

Idaho Falls, ID 83401

E. A. Jordan

U.S. Department of Energy

Washington, D.C. 20545

R. Watters

U.S. Department of Energy

Washington, D.C. 20545

D. E. Large

U.S. Department of Energy

Box E

Oak Ridge, TN 37830 
PNL $-4432-9$

\section{DISTRIBUTION}

No. of

Copies

L. J. Mezga

U.S. Department of Energy

Box X. Bldg. 1505

Oak Ridge, TN 37830

Dr. D. C. Haney

Kentucky Geological Survey

University of Kentucky

311 Breck inridge Hall

Lexington, KY 40506

Dr. W. D. Keller

Department of Geology

University of Missouri

Columbia, M0 65201

Dr. A. Kilinc

Department of Geology

University of Cincinnati

Cincinnat $\mathrm{i}, \mathrm{OH} 45221$

Dr. S. Leung

Department of Geology

Eastern Kentucky University

Richmond, KY 40475

R. Dayal

Brookhaven National Laboratory Building 830

Upton, NY 11973

R. F. Pietrzak

Brookhaven National Laboratory

Building 830

Upton, NY 11973

D. C. Schweitzer

Brookhaven National Laboratory

Building 830

Upton, NY 11973
No. of

Copies

J. Albanese

New York Geological Survey

Empire State Plaza

Albany, NY 12234

R. K. Schulz

University of California

Department of Soils and Plant Nutrition

Berkeley, CA 94720

P. L. Phelps

Lawrence Livermore National Laboratory

P.0. Box 5504, L-156

Livermore, CA 94550

W. L. Polzer

Los Alamos National Laboratory

Environmental Science

P.0. Box 1663

Los Alamos, NM 87545

H. H. Zehner

U.S. Geological Survey

1013 No. Broadway

Knoxville, TN 37917

A. L. Knight

U.S. Geological Survey, W.R.D.

Room 572 Federal Building

600 Federal Place

Louisville, KY 40202

J. Fischer

U.S. Geological Survey

Office of Radiohydrology

National Center MS 410

Reston, VA 22092 
PNL -4432-9

\section{$\underline{\text { DISTRIBUT ION }}$}

No. of

Copies

J. B. Robertson

U.S. Geological Survey

Office of Radiohydrology

National Center MS 410

Reston, VA 22092

T. Tamura

Union Carbide Corporation

Oak Ridge National Laboratory

P.0. Box X

Oak Ridge, TN 37830

2 H. D. Mills

Department for Natural Resources and Environmental Protection

Fort Boone Plaza

18 Reilly Road

Frankfort, KY 40601

J. E. Razor

Hittman Nuclear Development Corporation

Route 2, Box 238A

Hillsboro, KY 41049

D. T. Clark

Department for Human Resources

Commonwealth of Kentucky

275 East Main Street

Frankfort, KY 40601

W. Hipsher

U.S. Ecology, Inc.

9200 Shelbyville Road, Suite 526

Louisville, KY 40207

A. Armbrust

U.S. Ecology, Inc.

P.0. Box 158

Sheffield, IL 61361
No. of

Copies

D. D. Ed

Illino is Department of Nuclear Safety

1035 Outer Park Drive

Springfield, IL 62704

\section{ONSITE}

39 Pacific Northwest Laboratory

L. L. Eberhardt

M. G. Foley

E. A. Jenne

L. J. Kirby (15)

J. M. Latkovich

J. M. Nielsen

R. W. Perkins

S. R. Peterson

W. H. Rickard

D. E. Robertson

J. L. Swanson

C. W. Thomas

J. M. Thomas

A. P. Toste

C. M. Unruh

W. R. Wiley

R. E. Wildung

N. A. Wogman

Technical Information (5)

Publishing Coordination (2) 